This article was downloaded by: [Australian National University]

On: 10 February 2014, At: 22:51

Publisher: Routledge

Informa Ltd Registered in England and Wales Registered Number: 1072954 Registered

office: Mortimer House, 37-41 Mortimer Street, London W1T 3J H, UK

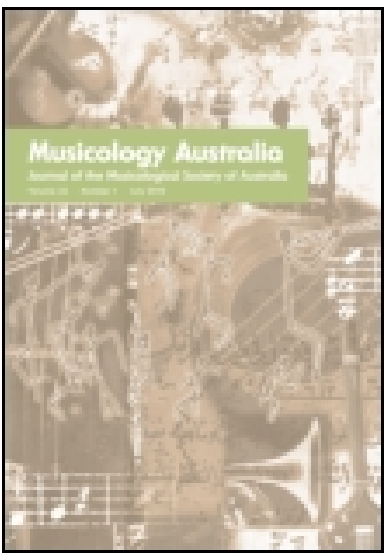

\title{
Musicology Australia
}

Publication details, including instructions for authors and subscription information:

http:// www. tandfonline.com/loi/ rmus20

\section{Sustaining Australia's Indigenous Music and Dance Traditions: The Role of the National Recording Project for Indigenous Performance in Australia}

\author{
Aaron Corn ${ }^{\mathrm{a}}$ \\ a The Australian National University, Canberra, Australia \\ Published online: 17 Dec 2013.
}

To cite this article: Aaron Corn (2013) Sustaining Australia's Indigenous Music and Dance Traditions: The Role of the National Recording Project for Indigenous Performance in Australia, Musicology Australia, 35:2, 268-284, DOI: 10.1080/08145857.2013.844526

To link to this article: http:// dx.doi.org/ 10.1080/08145857.2013.844526

\section{PLEASE SCROLL DOWN FOR ARTICLE}

Taylor $\&$ Francis makes every effort to ensure the accuracy of all the information (the "Content") contained in the publications on our platform. However, Taylor \& Francis, our agents, and our licensors make no representations or warranties whatsoever as to the accuracy, completeness, or suitability for any purpose of the Content. Any opinions and views expressed in this publication are the opinions and views of the authors, and are not the views of or endorsed by Taylor \& Francis. The accuracy of the Content should not be relied upon and should be independently verified with primary sources of information. Taylor and Francis shall not be liable for any losses, actions, claims, proceedings, demands, costs, expenses, damages, and other liabilities whatsoever or howsoever caused arising directly or indirectly in connection with, in relation to or arising out of the use of the Content.

This article may be used for research, teaching, and private study purposes. Any substantial or systematic reproduction, redistribution, reselling, loan, sub-licensing, systematic supply, or distribution in any form to anyone is expressly forbidden. Terms \& Conditions of access and use can be found at http://www.tandfonline.com/page/termsand-conditions 


\title{
Sustaining Australia's Indigenous Music and Dance Traditions: The Role of the National Recording Project for Indigenous Performance in Australia
}

\author{
AARON CORN \\ The Australian National University, Canberra, Australia
}

\begin{abstract}
This article examines the National Recording Project for Indigenous Performance in Australia as a dedicated network of Indigenous performers, and allied scholars and curators, to protect and sustain Australia's highly endangered traditions of Indigenous music, dance and ceremonies. The paper examines how the National Recording Project has developed into a community of practice for the making and archiving of Indigenous Australian music and dance recordings in response to Indigenous community agency and concerns, and how its annual Symposium on Indigenous Music and Dance has developed into a unique forum for intercultural exchange. Strategies for this initiative's future growth are identified and explored.
\end{abstract}

\section{Introduction}

Over the past decade, the National Recording Project for Indigenous Performance in Australia has grown into an expert intercultural and interdisciplinary coalition of concerned individuals and organizations with interests in protecting and sustaining Australia's highly endangered traditions of Indigenous creative expression through music, dance and ceremonial performance. The project hosts the annual Symposium on Indigenous Music and Dance from which it initially emerged, and publishes the Indigenous Music of Australia series of books and albums through Sydney University Press. Both the discovery of old existing recordings and the act of recording anew are facilitated by the National Recording project to bring apply such artefacts of lived experience in new ways that support and stimulate cultural continuity.

Informed by my own close collaborations with Indigenous and other colleagues in the formation of the National Recording Project since its inception, this article will examine how this initiative has coalesced into an effective community of practice around the making and archiving of Indigenous Australian music and dance recordings that marries academic and curatorial institutional expertise with grassroots community agency and concerns. The paper will explore the beginnings of the National Recording Project in our first symposium in Arnhem Land in 2002, our movements towards the establishment of agreed fieldwork and archiving protocols in 2005, the development of the symposium as a premier forum for intercultural exchange in Australia, our support for and facilitation of affiliated projects led by Indigenous people and communities, and, finally, current challenges and opportunities identified collaboratively with our partners for sustaining Australia's Indigenous performance traditions into the future. 


\section{Origins and Formative Collaborations}

The National Recording Project was conceived in August 2002 by delegates of the inaugural Symposium on Indigenous Music and Dance at Gunyanara in Arnhem Land, Australia, during the fourth Garma Festival of Traditional Culture hosted by the Yothu Yindi Foundation (YYF). ${ }^{1}$ Delegates at the inaugural meeting, which was funded by the Australian Institute of Aboriginal and Torres Strait Islanders Studies (AIATSIS), comprised a large cohort of Indigenous traditional artists and community leaders from Australia's north, and scholars of music, dance, Indigenous studies, languages and archiving engaged in long-term collaborations with them. It was convened by Mandawuy Yunupinu of YYF, Allan Marett of the University of Sydney, and Marcia Langton of the University of Melbourne, with myself serving as Secretary.

This initial symposium explored a broad range of possibilities for understanding, recording and circulating Indigenous performance traditions, which included performing and analysing traditional songs, transcribing and translating their lyrics, new media re-settings of traditional song materials, learning and performing traditional dances, and Indigenous archiving as a means of gathering and caring for localized collections. It attracted leading Indigenous performers from Gunyanara, Yirrkala, Galiwin'ku, Maningrida, Belyuen, Ngukurr and Borroloola; community stakeholders from regional schools, language centres and local government councils; ethnomusicologists, linguists and Indigenous experts from Australian tertiary institutions; and a contingent of scholars and archivists from the Institute for Papua New Guinea Studies (Marett et al. 2006, 84).

This broad representative cross-section of delegates identified common areas of concern for the continuation of endangered Indigenous traditions, the law and knowledge that they carry, and improved access to worldwide collections of these materials. From these discussions came the Garma Statement on Indigenous Music and Performance (Appendix 1), which was collaboratively drafted and ratified by delegates, and was launched before the festival's close. In brief, this statement called on the Australian Government:

- to establish Indigenous Knowledge Centres with digital storage and retrieval systems to enable the repatriation of audiovisual records to communities,

- to establish a National Recording Project for Indigenous Performance in Australia to ensure that the song and dance traditions of as many artists as possible are held for future generations,

- to support the recording of these traditions and the repatriation of resultant resources into local Indigenous Knowledge Centres so that they may be used across a broad range of community contexts, including education, language and health programs, to reinforce the stabilising social influence of ceremonial protocols and performances in all aspects of community life and governance, and,

- to support the publication of well-documented recordings of Indigenous song traditions as a means of educating the broader public in Australia and internationally. (YYF 2002, pp. 1-2)

Two years later, during the sixth Garma Festival in Arnhem Land, the National Recording Project was launched at Gulkula following our third Symposium on Indigenous Music and Dance. Allan Marett took on the role of founding Director in a voluntary capacity, and

1 All spellings of names and words from the Yolnu languages follow the conventions used today throughout the Yolyu communities of Arnhem Land (Zorc 1996). 
throughout 2005 we undertook two pilot studies in the project's name. The first, funded by the Australian Research Council (ARC), provided for a series of meetings with potential stakeholders from a wide range of Indigenous communities, industry partners, universities and collecting institutions to establish the National Recording Project's governance structure, and archiving arrangements with AIATSIS and the Northern Territory Library. ${ }^{2}$ The second pilot study, funded by the University of Sydney, provided for a series of collaborative field trips to remote locations across Arnhem Land, led by their senior traditional holders including Mandawuy Yunupinu, to test new equipment and techniques for digitally capturing, storing and repatriating high-fidelity recordings of their incumbent song repertoires. ${ }^{3}$ These trips into Arnhem Land also enabled new comprehensive recordings of song series in the eastern manikay tradition of the Yolnu and the western kunborrk tradition of the Bininj (Marett et al. 2006, 87).

Findings from both pilot studies directly informed the National Recording Project's initial fieldwork and archiving protocols, and were launched in Melbourne in a keynote address by Allan Marett, Mandawuy Yunupinu, Marcia Langton, Neparrna Gumbula, Linda Barwick and myself at the Australia Council of the Arts' National Education and the Arts Symposium in September 2005 (Marett et al. 2006).

From this formative period also came the National Recording Project's first edited volume of articles on Indigenous songs from Indigenous, musical and linguistic perspectives. Published by AIATSIS as the second issue of Australian Aboriginal Studies for 2007, this volume spans work by project partners on the kunborrk tradition of western Arnhem Land (Barwick, Birch, and Evans 2007; Garde 2007; Marett and Barwick 2007; O'Keeffe 2007), the wangga tradition of the Daly River region (Ford 2007; Marett 2007), the junba tradition of the Kimberley region (Treloyn 2007), central Australian songs (Turpin 2007), the manikay tradition of eastern Arnhem Land (Corn and Gumbula 2007), and overarching questions about language use in Indigenous songs (Walsh 2007).

My own article in this volume, co-authored with the Yolnu elder, scholar and ceremonial leader Neparrna Gumbula, stems from collaborative field trips we undertook with his family to their homeland, Djiliwirri, in June 2004 and July 2005. Our aims were to make a complete digital recording of a hereditary song series as sung by Gumbula and his siblings, and to capture stories, images and geospatial data for related sites on this country. Unlike a conventional ethnographic exercise in which a researcher might passively record whatever activities the host community may be undertaking at the time, our approach at Djiliwirri, which we adopted for similar field trips to Lungutja, Gurrumuru, Wandawuy and Biranybirany in 2005 and 2006, constituted an intentional attempt by Yolnu leaders to perform their own repertoires for posterity in an enduring archival record (Corn and Gumbula 2007).

\section{Present Aims and Activities}

Since those formative years, the National Recording Project has developed into an expert coalition of concerned individuals and organizations with interests in protecting and

2 Allan Marett, Linda Barwick, Marcia Langton, Aaron Corn, Mandawuy Yunupinu, Alan James and Witiyana Marika, 'Planning for Sustainability of the National Indigenous Recording Project: A Pilot Project' (ARC 2005), Linkage Project.

3 Aaron Corn and Allan Marett, 'Realising Performance Traditions on Country: A Pilot Study Towards the National Recording Project for Indigenous Performance in Australia' (The University of Sydney 2005), Research and Development Grant. 
sustaining Australia's highly endangered traditions of Indigenous of creative expression through music, dance and ceremonial performance, and has been active in the following:

- recording traditional music, dance and ceremony in cooperation with local Indigenous communities;

- repatriating archival records of music, dance and ceremony to Indigenous communities following world's best practice;

- assisting communities to integrate these materials into broader education, languages, health, governance and business programmes;

- promoting and assisting in the creation of local digital archives of traditional music, dance and ceremony within Indigenous communities;

- encouraging safe archival storage under agreed protocols at AIATSIS in partnership with local digital archives;

- publishing books and albums of traditional music and dance under the Indigenous Music of Australia label, published by Sydney University Press, to promote them as an integral part of Australia's cultural life;

- raising awareness via publications, education and the media about the crisis afflicting Australia's traditions of Indigenous music, dance and ceremony;

- promoting traditional performance and cultural sustainability as major beneficial factors in strengthening Indigenous health, education and employment;

- stimulating local community development through Indigenous arts programmes to support infrastructure needs and economic growth within Australia's regions; and

- organizing the annual Symposium on Indigenous Music and Dance, which draws together leading Indigenous artists from throughout Australia with key experts from universities, collecting institutions and industry partners.

All official positions on the National Recording Project remain voluntary, and there are no membership fees of any kind. However, new parties wishing to be affiliated with the National Recording Project are normally invited to present on their work at the next Symposium on Indigenous Music and Dance first. On the day prior to each symposium, an Annual General Meeting is held for all partners, and a meeting of the Steering Committee immediately follows.

The project is presently led by two Co-Directors: myself and Payi-Linda Ford of the University of Queensland, who is an education scholar of Marranunggu descent from Finniss River in the Northern Territory. Allan Marett remains active as Co-Chair of the Steering Committee alongside the Mawng elder and ceremonial leader David Manmurulu, from Warruwi in Arnhem Land. Others who sit on the Steering Committee represent the project's broad community and institutional partnerships, and bring essential cultural, technical and scholarly expertise to bear in shaping present and future directions. These members presently are:

- Kevin Bradley, Director of Sound Preservation at the National Library of Australia;

- Neparrya Gumbula, a Yolnu elder and ceremonial leader who holds an ARC Australian Research Fellowship at the University of Sydney;

- Cathy Hilder, Manager of Public Library Services at the Northern Territory Library;

- Marcia Langton, Chair of Australian Indigenous Studies at the University of Melbourne; 
- Wanta Patrick, a Warlpiri elder and ceremonial leader who serves as Creative Director of the Milpirri Festival at Lajamanu;

- Russell Taylor, Principal of AIATSIS who is represented at meetings by sound archiving expert Grace Koch;

- Wukun Wanambi, Director of the Mulka Project at Yirrkala; and

- Stephen Wild, Vice-President of the International Council for Traditional Music.

Sally Treloyn of the University of Melbourne serves as Secretary to the Steering Committee, while Linda Barwick of the University of Sydney is General Editor of the project's publications series, the Indigenous Music of Australia. Published by Sydney University Press, our titles to date include the album Wurrurrumi Kun-borrk: Songs from Western Arnhem Land by Kevin Djimarr (2007), and my own book Reflections and Voices: Exploring the Music of Yothu Yindi with Mandawuy Yunupinu (Corn 2009). This new series of books and albums particularly builds on Allan Marett and Linda Barwick's long experience and expertise in recording, documenting and publishing a broad array of Australia's endangered Indigenous traditions in collaboration with leading performers from Barunga (Maralung 1993), Tennant Creek (Papulu Apparr-kari Language and Culture Centre 2000), Belyuen (Lane 2001), Dodnun (Martin 2003), Minjilang (Cooper et al. 2005) and Wadeye (Marett 2005).

The National Recording Project's core strengths lie in its longitudinal history of consultation and action around issues of how best to maintain, strengthen and enliven Australia's highly endangered traditions of Indigenous music and dance, and in implementing collaborative projects that support these aims. While the project receives no operational funding of any kind, project partners have nonetheless been highly successful in attracting a large number of research grants and industry consultancies to support Indigenous communities in maintaining their endangered performance traditions.

While the National Recording Project maintains a vibrant and active network of interested partners, there is no master task-list that determines and prioritizes what content should be recorded. As such, the project, which is perhaps more correctly described as an expansive longitudinal meta-project, is always a composite of its partners' various localized interests and priorities as shaped through direct consultation with the communities from which they come or with which they work. Since 2004, these partners have secured nearly $\$ 8$ million from granting bodies for research that supports the survival of Indigenous performance repertories and related languages. Spanning some thirty discrete studies to date, these include a core series of grants funded competitively by the ARC, AIATSIS, the Hans Rausing Endangered Languages Documentation Project, and the Volkswagen Foundation.

Recent examples of these grants, which have each enabled endangered song traditions to be locally recorded, documented and revitalized in response to close community consultations, include work by Stephen Wild on Warlpiri songs of the Tanami Desert, by Nicholas Evans on song and language traditions of northwestern Arnhem Land, by Margaret Gummow on traditional song revilatization in northern New South Wales, by Sally Treloyn on the junba tradition of the Kimberley, by Myfany Turpin on central Australia songs, and by Genevieve Campbell on song traditions of the Tiwi Islands. ${ }^{4}$ Also

4 Stephen Wild, 'Milpirri: A Revitalisation Movement in Central Australia' (AIATSIS 2009), Research Grant. Nicholas Evans, Sabine Höng, Linda Barwick, Bruce Birch, Robert Mailhammer, Gretel Schwörer-Kohl and Dietmar Zaefferer, 'Inyman Kalmu: Languages of the Cobourg Region, North Australia, Phase II' 
represented among these grants is research into the development of better digital archiving techniques and interfaces for Indigenous communities and their institutional partners. This includes my own present study into the application of Semantic Web techniques to organizing collections data and metadata, including intermedia geo-tagging and rights management information, according to Indigenous knowledge structures. ${ }^{5}$

The overarching aims and applied collaborative methods of the National Recording Project align particularly well with the National Research Priorities that the ARC takes into account when allocating funding. Specifically, they hold demonstrable relevance to the National Research Priority Goals for 'Strengthening Australia's Social and Economic Fabric', 'Smart Information Use' and 'Promoting an Innovation Culture and Economy', as well as the ARC's own occasional Special Interests in 'Indigenous Australian Societies' and 'Indigenous Health and Well-being' (Australian Government 2003).

To date, these grants have additionally provided for nine fixed-term research fellowships and two cadetships, which comprise a total of thirty-five years of full-time employment for researchers working with communities to maintain Australia's endangered Indigenous performance traditions. Moreover, three of these fellowships, and both cadetships, have gone to Indigenous scholars for related research into untapped existing collections of their own communities' cultural heritage (Gumbula 2005, 2009, 2011; Gumbula, Corn, and Mant 2009). The first and second of these Indigenous fellowships, commencing in 2007 and 2010, went to Neparrya Gumbula, who is now the first Yolyu Australian in history to have led an ARC project of any kind. ${ }^{6}$ The third, commencing in 2012, was won by Wanta Patrick, who has similarly become the first Warlpiri Australian to lead an ARC project. $^{7}$

\section{A Symposium of Intercultural Exchanges}

Since its inauguration in 2002, the Symposium on Indigenous Music and Dance has been held each year as a single-stream event, and is now maintained as the National Recording Project's key annual event. The first five of these symposia from 2002 to 2006 were

Footnote 4 continued

(Volkswagen Foundation 2009-2010), Documentation of Endangered Languages Project. Margaret Gummow, John Giacon and Suellyn Tighe, 'Revitalising Gamilaraay Songs and Dances: Using New Technologies to Create Community-based Resources' (AIATSIS 2010), Research Grant. Sally Treloyn and Allan Marett, 'Strategies for Sustaining Aboriginal Song and Dance in the Modern World: The Mowanjum and Fitzroy River Valley Communities of Western Australia' (ARC 2009-2012), Linkage Project. Myfany Turpin (Australian Postdoctoral Fellowship), 'Singing the Dreaming: Exploring the Relationship between Language and Music in Arandic Song-Poetry' (ARC 2010-2012), Discovery Project. Ngarukuruwala, 'To Develop Music Resources from Archived Material to Preserve and Maintain Tiwi Language and Song Practice' (Australia 2011), Maintenance of Indigenous Languages and Records Grant.

5 Aaron Corn (Future Fellowship), 'Indigenising the Semantic Web: Ontologies for Indigenous Knowledge and Heritage Resources on a Machine-readable Web' (ARC 2009-2013), Future Fellowships Project.

6 Neparnya Gumbula (Indigenous Research Fellow) and Aaron Corn, 'Elder Assessments of Early Material Culture Collections from Arnhem Land and Contemporary Access Needs' (ARC 2007-2008), Discovery Indigenous Researchers Development Project. Neparrna Gumbula (Australian Research FellowIndigenous), 'To Wake Them Up Again: Digital Futures for the International Diaspora of Early Ethnographic Collections from Arnhem Land' (ARC 2010-2012), Discovery Indigenous Researchers Development Project.

7 Wanta Patrick (Discovery Indigenous Award), Aaron Corn and Stephen Wild, 'Early Collections of Warlpiri Cultural Heritage and Resulting Community Access Needs in Remote Desert Australia' (ARC 2012-2014), Discovery Indigenous Project. 
convened at the Garma Festival of Traditional Culture in August in close collaboration with this overarching event's Yolnu hosts and YYF. They also became a significant component of the immersive 'Garma Fieldwork' courses that I taught with Marcia Langton through the University of Melbourne until 2004 and subsequently introduced to the University of Sydney (Corn 2011a, 31-45). In 2004 and 2005, we also sponsored international artists to visit Arnhem Land to participate in the symposium and the festival's performance programme. The first of these in 2004 were the Bauls of Bengal, who shared their experiences of sustaining their own endangered music tradition and building for it an international audience base. The second in 2005 were Takbing Siwaliya from Makassar on the Indonesian island of Sulawesi, who came to explore, through ceremonial performance and collaboration, the continuous trade and cultural relations that their forebears had once held with Indigenous peoples of north Australia up until the first decade of the twentieth century (Corn and Marett with Garawirrtja 2011).

For the 2006 symposium, this focus shifted to a new musical collaboration that was then just emerging between Yolyu manikay performers from Ngukurr in southeast Arnhem Land and the Australian Art Orchestra based in Melbourne, and as a result festival patrons were able to witness the very first public performances of their ever-evolving collaborative work, Crossing Roper Bar (Australian Art Orchestra 2010). From 2007 to 2009, the sixth to eighth symposia were hosted by Charles Darwin University on the Casuarina Campus in Darwin, where they were concurrently programmed as an event of the Darwin Festival in August. In 2009 we also convened a special forum later in August at the University of Melbourne that focused on the activities of Indigenous communities and artists in Australia's southeast with valuable contributions from soprano-composer Deborah Cheetham, who directs the Wilin Centre for Indigenous Arts at the University of Melbourne, and the Koori Heritage Trust, which the State of Victoria's statutory Indigenous memory institution. This event coincided with a performance that evening of Crossing Roper Bar in the Melbourne Recital Centre, and so the musicians involved in this collaboration including Paul Grabowsky, the Australian Art Orchestra's Artistic Director, also presented at the forum.

The ninth symposium was convened in July 2010 at the National Film and Sound Archive in Canberra, and held in conjunction with the AIATSIS Information Technologies and Indigenous Communities Symposium, which I concurrently convened with Lyndon Ormond-Parker from the University of Melbourne and Cressida Fforde from AIATSIS in the adjacent Australian Academy of Science Shine Dome. Initially, we had envisaged that this joint symposium would be a modest affair attracting some thirty speakers. Yet our call for papers elicited an overwhelmingly strong response from many high-quality presenters, and we were soon faced with the need to programme up to three parallel sessions. All told, some 250 delegates gathered for this symposium to share in the presentation of more than seventy papers and workshops that revealed the staggering strength, breadth and vibrancy of grassroots Indigenous engagements with information technologies throughout Australia, and also further afield in New Zealand and Canada. The many savvy initiatives discussed there revealed a compelling groundswell of Indigenous expertise in information technology applications for education, health, heritage, languages, mapping, creative arts and broadcasting that is now contributing considerably to improving quality of life, educational outcomes and economic futures for Indigenous Australians (AIATSIS 2010).

Finally, our tenth symposium returned to Darwin, where it was convened on the North Australia Campus of the Australian National University in August 2011. A significant 
outcome of this meeting was the formal commissioning of a traditional mamurrng ('gifting') ceremony from northwest Arnhem Land to affirm the accord that has now been well established between the National Recording Project's two Steering Committee CoChairs, David Manmurulu and Allan Marett (Altman 1987, 202; Corn 2002, 87-8; Garde 1998, 6). Allan Marett was invited to make this commission by David Manmurulu and Charlie Mangulda, who are senior leaders of the mamurrng ceremony in northwest Arnhem Land.

Over the decade of its existence, the Symposium on Indigenous Music and Dance has grown into a meeting that brings together senior Indigenous law-holders and cultural practitioners, ethnomusicologists, archivists, linguists, librarians, lawyers, historians and others to exchange ideas and information on a broad range of local, regional and national recording, collections and cultural revitalization initiatives across Australia. Our sessions typically address a wide array of concerns including musical, choreographic and linguistic processes in Indigenous music and dance traditions, the contemporary application of these traditions to new intercultural initiatives such as the Milpirri Festival at Lajamanu, and resource management and community access issues for related materials held in existing and developing collections locally, nationally and internationally. We also discuss community initiatives to apply ceremonial knowledge to a range of localized health, education, governance and legal programmes, and consider what Indigenous performance traditions can tell us about the nature of knowledge itself.

Under the guidance of traditional exponents, live performances of rare song and dance repertoires often bloom into profound discussions of their sacred resonances with kin, country and ancestors, while otherwise conventional analytical papers can similarly erupt into responsive live performances by Indigenous delegates. These cross-media intercultural dialogues have ensured that the National Recording Project remains engaged with and responsive to the epistemological bases of its Indigenous community partners' values, needs and concerns in all work involving the precious cultural resources that their performance traditions comprise. As the only annual meeting that encourages and fosters this depth of direct collaboration among Australia's most prolific Indigenous traditional performers, and the broad network of curators, technical experts and academics working in allied fields, it is unique internationally.

The symposium's emphases on collaboration and dialogical consensus-building among these disparate parties owes much to its beginnings in the Garma Festival of Traditional Culture, which itself was greatly influenced by the ethos of bi-culturalism that Mandawuy Yunupinu instilled throughout his work as an educator in local Arnhem Land schools, as well as his work as a musician in the celebrated band, Yothu Yindi, and its philanthropic offshoot, YYF. Modelled primarily on the traditional Yolnu concept of ganma ('converging currents'), which marks the places on Yolyu homelands where different waters flowing from the countries of different clans meet as discrete and equal forces, Yunupinu envisaged the Garma Festival as a forum for intercultural dialogue aimed at generating new knowledge and understanding among different peoples without seeking to assimilate them under any universalizing mono-cultural meta-narrative (Morphy 1991, 70; Neuenfeldt 1993; Stubington and Dunbar-Hall 1994; Yunupinu 1994; Corn 2005, 2009, 2010).

Stemming from this vision through its formative years at the Garma Festival is a fundamentally collaborative paradigm in which it is not the role of the National Recording Project to dictate who records what. This, in turn, is a further development on ethnomusicology's own intimate relationship with Indigenous musicians in Australia, and 
its transformation in the 1980s from a discipline predicated on distant taxonomical concerns and salvage research into one that can reshape itself in dialogue with the changing needs and aspirations of the communities whose cultures it examines (Koch 2008; Corn 2011a, 24-5). The National Recording Project's approach is therefore to inspire, empower and facilitate people working with and from within local communities to do this for themselves, yet from within a collegial national network that enables them to draw on the technical and operational expertise of larger institutional partners such as AIATSIS and the National Library of Australia when needed.

As an interdisciplinary and intercultural network of partners, the National Recording Project also fundamentally appreciates and embraces the multiple interwoven literacies that Indigenous knowledge systems foster, and through which music and dance are commonly recognized as formal media for the recording of history, the reckoning of ancestral lineages, the evidencing of heredity rights over country and other property, and the execution of due legal process. We also acknowledge the formal standing and expertise of law-holders, who have been educated through these Indigenous knowledge systems, as intellectuals and intercultural agents in their own right, hence our support for Indigenous elders such as Neparrna Gumbula and Wanta Patrick in pursuing research interests that are directly informed by their own communities' needs (Corn and Gumbula 2004, 2006; Patrick, Holmes, and Box 2008). This sets the National Recording Project apart quite markedly from most other organizations in Australia, which are conventionally driven by Anglophone approaches to academic and policy concerns.

\section{Challenges and Opportunities Ahead}

The transformation of recording media from wax cylinder to solid-state hard drives within the span of a century has unquestionably revolutionized the ability to capture and return high-quality sound recordings to Indigenous communities with unprecedented ease and rapidity. Yet there are nonetheless pressing constraints that need to be addressed before all existing calls from Indigenous communities for better support in sustaining their performance traditions into the future can be met. The National Recording Project has strived for a decade now to draw attention to this crisis. Since the beginning of British settlement in Australia, the attrition of these traditions has been massive. We estimate that more than ninety-eight per cent of all traditions that were present then in January 1788 have been lost, and all surviving traditions that remain today are highly endangered. The efforts that Indigenous peoples continue to make to keep these traditions alive are immense, which is indicative of their intrinsic high value to Indigenous communities. Even so, the overarching socio-economic and political pressures that Indigenous communities in Australia continue to face constitute a persistent threat to their continuing survival (Australian Government 1997, 2007; Corn 2001, 2007, 2011b; Perkins and Langton 2008; Yunupinu 2009).

As Australia has not yet signed the UNESCO Convention for the Safeguarding of the Intangible Cultural Heritage (UNESCO 2003), in July 2011 the General Assembly of the International Council for Traditional Music (ICTM), a non-governmental organization in Formal Consultative Relations with UNESCO, formally recognized the crisis of Australia's Indigenous performance traditions and called for urgent action with its unanimous endorsement of the ICTM Statement on Indigenous Australian Music and Dance (Appendix 2). This is the first time in ICTM's seven-decade history that it has taken such action in the hope that urgent measures will be taken to 'ensure the protection 
of those living practices that remain, for the benefit of all Australians, and for cultural diversity worldwide' (ICTM 2011, 1).

The increasing affordability and accessibility of digital technologies that enable Indigenous peoples to create and access records of their traditional cultures are already offering beneficial ways forward to this end, and the National Recording Project strongly advocated their use. For several decades now, Indigenous performers have used audiovisual media to support the intergenerational transmission of traditions, and over the past decade partners of the National Recording Project have trialled and tested the use of digital repositories as electronic keeping places designed to support traditional performance activities in numerous Indigenous communities (Marett et al. 2006, 85-6). These include the Northern Territory Library's Community Stories database based on the Ara Irititja software developed by the Pitjatjantjara Council, and the Wadeye Song Database developed through the Murriny Patha Song Project with the Wadeye Aboriginal Languages Centre and the Wadeye Knowledge Centre (Ara Irititja Project 2011; Northern Territory Library 2011; PARADISEC 2011). ${ }^{8}$

As identified at the Information Technologies and Indigenous Communities Symposium in July 2010, which the National Recording Project convened in partnership with AIATSIS, there is also a groundswell of enthusiasm for the uptake of new technologies among young Indigenous Australians that now provides a fertile context for digital media initiatives that link local communities into broader social and professional networks, and are simultaneously aimed at strengthening Indigenous health, education and employment (AIATSIS 2010). Compelling examples of such community initiatives include Ngaanyatjarra Media in Alice Springs, which uses media and communications technologies to tell Indigenous stories of the Western Desert region, and the Mulka Project at Yirrkala, which provides meaningful employment to Yolnu communities through multimedia cultural heritage programmes and has recently launched its own series of traditional music albums (Buku-Larrngay Mulka Art Centre 2011; PYMedia 2011).

While indeed there is great need for more secure sources of income to support training and employment in this burgeoning field, so that Indigenous communities are empowered to collect and curate their own cultural records, the equipment, infrastructure and maintenance required to sustain such initiatives also impose considerable recurrent costs, particularly in regional and remote community contexts where suppliers and service providers are scarce. Computer terminals and hard drives cannot simply be loaded with content by visiting agents as a one-off exercise and then forgotten. Over time, hardware fails and software corrupts, and without sufficient funds for maintenance, upgrading and replacement, even robust facilities will inevitably fail. This is indeed why regional networks like the Ara Irititja and Community Stories databases, which are able to share not only content but also technical and operational training and expertise across multiple communities simultaneously, are crucial to the sustainability of digital recording and archiving endeavours both locally and nationally.

The National Recording Project has recently addressed these pressing concerns in its formal response to the Australian Government's National Cultural Policy Discussion Paper (Australian Government 2011a), in which we propose that the decline and future loss of the Australia's remaining Indigenous music and dance traditions can be arrested through the establishment of a fund, to be administrated through AIATSIS, that is similar to the

8 Marett, Allan, Michael Walsh, Nicholas Reid and Lysbeth Ford, 'Preserving Australia's Endangered Heritages: Murrinh-patha Song at Wadeye' (ARC 2004-2008), Discovery Project. 
present Indigenous Languages Support scheme for the protection and revitalization of Indigenous languages (Australian Government 2011b). ${ }^{9}$ Grants from this fund would be made available to Indigenous organizations with encouragement to apply for triennial funding. While individual grants would differ markedly in size, scope, geography and immediacy, given the persistent threat to the survival of these traditions, we consider that triennial funding of up to $\$ 250,000$, to be drawn from a total budget of $\$ 5$ million annually, would be justified. If such resources could be provided, it would be possible to slow and reverse the decline of surviving traditions, and for lost traditions to revive them from existing records now and into the future. Indigenous peoples in New South Wales and Victoria are even now carefully reviving long-lost traditions by consulting a variety of records both ancient and modern, and in northern Australia musicians and dancers have regularly consulted audiovisual records as an aid to performance for several decades now.

Our long experience shows that there are a variety of organizations that could host and implement projects aimed at supporting traditional music and dance, and that Indigenous communities themselves are best placed to nominate appropriate host organizations, which could include arts centres, language centre, libraries, ranger programmes, schools, health clinics, aged care facilities, community councils and community centres. Although they would require assistance in key technical areas, these kinds of local organizations are in the best position to determine what is needed and what will work best at local and regional levels, and there are far greater chances of endangered music and dance traditions being sustained into the future if they are embedded in the daily business of local services and organizations that will have the most immediate needs for regular usage of the materials recorded. With the National Recording Project providing advice to communities on preparing applications and project implementation, this programme would be tightly focused on:

- the recording and documentation of existing traditions at world's best practice standards;

- the development of local communities through related Indigenous arts programmes that support infrastructure needs and economic growth within Australia's regions;

- the location and return to the community of relevant archival records;

- the establishment of local digital archives to facilitate dissemination of material according to appropriate cultural protocols;

- safe archival storage under agreed protocols at AIATSIS in partnership with local digital repositories; and

- the creation of books, recordings, websites and teaching materials in close partnership with Indigenous communities to assist in the education of the broader Australian public about Indigenous music and dance.

With AIATSIS administrating any potential funds to come through the National Cultural Policy, the National Recording Project's advice to communities would be provided in the form of consultancies, with all consultants working within our agreed protocols (Marett et al. 2006). In formulating this scheme, we would also offer advice to and facilitate dialogue between communities and government on the preservation and maintenance of endangered indigenous performance traditions with the aims of:

9 I edited this response based on an initial draft by Allan Marett with substantial contributions by David Manmurulu, Payi-Linda Ford, Russell Taylor, Sally Treloyn and Grace Koch (National Recording Project for Indigenous Performance in Australia 2011). 
- developing projects to sustain local traditions;

- recording and documenting traditional Indigenous music and dance, and training of local Indigenous people to undertake this work;

- strengthening local communities through related Indigenous arts programmes that support infrastructural needs and economic growth within Australia's regions;

- locating and repatriating existing archival records;

- creating and managing local digital archives;

- safe archival storage under agreed protocols at AIATSIS in partnership with local digital repositories; and

- creating publications and websites including teaching materials for use at all levels of education.

\section{Conclusions}

At the heart of the National Recording Project's successes to date is its network of people: the broad collection of Indigenous law-holders and cultural practitioners that gather with concerned ethnomusicologists, archivists, linguists, librarians, lawyers, historians and others at each year's symposium to exchange ideas and information on a broad range of local, regional and national recording, collections and cultural revitalization initiatives across Australia. More than anything else, our relationships across communities, cultures and sectors drives the viability of the National Recording Project as a conduit for propelling community engagement with recording and archiving, and their dynamism as catalysts for cultural survival into the future.

This article has shown how the National Recording Project grew out of the first Symposium on Indigenous Music and Dance at the Garma Festival of Traditional Culture in August 2002, which was itself a product of Mandawuy Yunupinu's influential ethos of ganma bi-culturalism, and how through its vibrant cross-media exchanges this forum remains unique internationally in fostering engagement with and responsive to the epistemological bases of our Indigenous community partners' values, needs and concerns in all work involving the precious and irreplaceable cultural resources that their performance traditions comprise. While the tasks of stemming and, wherever possible, reversing the attrition of these music and dance traditions are indeed daunting, the decade-long experience of the National Recording Project nonetheless demonstrates how fostering such networks, nurturing research leadership among Indigenous elders in response to local community needs, and building on the present groundswell of enthusiasm for making use of digital media among young Indigenous Australians provide fertile new opportunities for Indigenous communities to record, archive and sustain their own performance traditions into the future. The National Recording Project advocates that sustaining Australia's endangered traditions of Indigenous music, dance and ceremonial performance should be a central pillar of any national cultural policy now and in the future, and as outlined in this article, that a dedicated grants fund should be established to support Indigenous communities in their ongoing maintenance and revitalization.

\section{References}

Australian Institute of Aboriginal and Torres Strait Islander Studies (AIATSIS) (2010), Statement on Key Issues identified at the Information Technologies and Indigenous Communities (ITIC) Symposium, Canberra, 13-15 July. Canberra: AIATSIS. 
Altman, Jon (1987), Hunter-Gatherers Today: An Aboriginal Economy in North Australia. Canberra: Australian Institute of Aboriginal Studies.

Ara Irititja Project (2011), (Accessed 22 December 2011), http://www.irititja.com

Australian Government (1997), Bringing Them Home: Report of the National Inquiry into the Separation of Aboriginal and Torres Strait Islander Children from Their Families. Canberra: Human Rights and Equal Opportunity Commission.

Australian Government (2003), The National Research Priorities and Their Associated Priority Goals. Canberra: Department of Education, Science and Training.

Australian Government (2007), Submission of the Human Rights and Equal Opportunity Commission (HREOC) to the Senate Legal and Constitutional Committee on the Northern Territory Emergency Response Legislation, 10 August 2007. Canberra: Human Rights and Equal Opportunity Commission.

Australian Government (2011a), National Cultural Policy Discussion Paper. Canberra: Office of the Arts.

Australian Government (2011b), 'Indigenous Languages Support (ILS)', Office for the Arts (Accessed 22 December 2011), http://arts.gov.au/indigenous/ils.

Australian Art Orchestra (2010), Crossing Roper Bar. Melbourne: Australian Art Orchestra.

Barwick, Linda, Birch, Bruce, and Evans, Nicholas (2007), 'Iwaidja Jurtbirrk Songs: Bringing Language and Music Together'. Australian Aboriginal Studies 2007/2: 6-34.

Buku-Larrygay Mulka Art Centre, 'The Mulka Project', Buku-Larrygay Mulka, Yirrkala NT (Accessed 22 December 2011), (http://www.yirrkala.com/themulkaproject).

Cooper, Reggie, et al. (2005), Jurtbirrk: Lovesongs from Nortbwestern Arnhem Land. Batchelor: Batchelor Press.

Corn, Aaron (2001), Ngukurr Crying: Male Youth in a Remote Indigenous Community. Wollongong: University of Wollongong.

Corn, Aaron (2002), 'Burr-Gi Wargugu Ngu-Ninya Rrawa: Expressions of Ancestry and Country in Songs by the Letterstisand'. Musicology Australia 25/1: 76-101.

Corn, Aaron (2005), 'When the Waters Will Be One: Hereditary Performance Traditions and the Yolnu Reinvention of Post-Barunga Intercultural Discourses'. Journal of Australian Studies 84 15-30.

Corn, Aaron (2007), 'To See Their Fathers' Eyes: Expressions of Ancestry, Fraternity and Masculinity in the Music of Popular Bands from Arnhem Land, Australia', in Freya Jarman-Ivens, (ed.), Ob Boy! Masculinities and Popular Music. Oxford: Routledge, 77-99.

Corn, Aaron (2009), Reflections and Voices: Exploring the Music of Yothu Yindi with Mandawuy Yunupinu. Sydney: Sydney University Press.

Corn, Aaron (2010), 'Land, Song, Constitution: Exploring Expressions of Ancestral Agency, Intercultural Diplomacy and Family Legacy in the Music of Yothu Yindi with Mandawuy Yunupinu'. Popular Music 29/1: $81-102$.

Corn, Aaron (2011a), 'Sound Exchanges: An Ethnomusicologist's Approach to Interdisciplinary Teaching and Learning in Collaboration with a Remote Indigenous Australian Community'. The World of Music 51/3: $19-48$.

Corn, Aaron (2011b), 'Treaty Now: Popular Music and the Indigenous Struggle for Justice in Contemporary Australia', in Ian Peddie, (ed.), Popular Music and Human Rights 2: World Music. Farnham: Ashgate, 17-26.

Corn, Aaron and Gumbula, Neparrna (2004), 'Now Balanda Say We Lost Our Land in 1788: Challenges to the Recognition of Yolnu Law in Contemporary Australia', in Marcia Langton, Maureen Tehan, Lisa Palmer and Kathryn Shain, (eds), Honour among Nations? Treaties and Agreements with Indigenous Peoples. Melbourne: Melbourne University Publishing, 101-114.

Corn, Aaron and Gumbula, Neparrna (2006), 'Rom and the Academy Repositioned: Binary Models in Yolnu Intellectual Traditions and Their Application to Wider Intercultural Dialogues', in Lynette Russell, (ed.), Boundary Writing: An Exploration of Race, Culture and Gender Binaries in Contemporary Australia. Honolulu: University of Hawai’i Press, 170-197.

Corn, Aaron and Gumbula, Neparrna (2007), 'Budutthun Ratja Wiyinymirri: Formal Flexibility in the Yolyu Manikay Tradition and the Challenge of Recording a Complete Repertoire'. Australian Aboriginal Studies 2007/2: 116-127.

Corn, Aaron and Marett, Allan with Djangirrawuy Garawirrtja (2011), 'To Proclaim They Still Exist: The Contemporary Yolngu Performance of Historical Makassan Contact', in Alejandra Duschatzky and Stephanie Holt, (eds), Trepang: China and the Story of Makassan-Aboriginal Trade. Melbourne: The University of Melbourne, 73-79.

Djimarr, Kevin (2007), Wurrurrumi Kun-borrk: Songs from Western Arnhem Land. Sydney: Sydney University Press.

Ford, Lysbeth (2007), “Too Long, That Wangga': Analysing Wangga Texts Over Time'. Australian Aboriginal Studies 2007/2: 76-89.

Garde, Murray (1998), 'From a Distance: Aboriginal Music in the Maningrida Community and on Their Internet Site'. Perfect Beat 4/1: 4-18.

Garde, M. (2007), 'Morrdjdjanjno ngan-Marnbom Story Nakka 'Songs That Turn Me into a Story Teller': The Morrdjdjanjno of Western Arnhem Land'. Australian Aboriginal Studies 2007/2: 35-45.

Gumbula, Neparrna (2005), 'Exploring the Gupapuypu Legacy: Strategies for Developing the Galiwin'ku Indigenous Knowledge Centre'. Australian Academic and Research Libraries 36/2: 23-26. 
Gumbula, Neparrna (2009), Makarr-Garma: Aboriginal Collections from a Yolnu Perspective. Sydney: The University of Sydney.

Gumbula, Neparrna (2011), Matjabala Mali' Buku-Runanmaram: Images from Milininbi (Milingimbi) and Surrounds, 1927-1962. Sydney: Darlington Press.

Gumbula, Neparrna, Corn, Aaron, and Mant, Julia (2009), “Matjabala Mali’ Buku-Ruyanmaram: Implications for Archives and Access in Arnhem Land'. Archival Science 9/1-2: 7-14.

International Council for Traditional Music (ICTM) (2011), Statement on Indigenous Australian Music and Dance. Brisbane: Regional Committee for Australian and New Zealand.

Koch, Grace (2008), 'Music and Land Rights'. Fontes Artis Musicae 55 155-164.

Lane, Bobby (2001), Rak Badjalarr: Wangga Songs for North Peron Island by Bobby Lane. Canberra: Aboriginal Studies Press.

Maralung, Alan (1993), Bunggridj-bunngridj: Wangga Songs by Alan Maralung, Northern Australia. Berlin: Smithsonian Folkways. http://www.artistdirect.com/nad/store/artist/album/019719000.html?src=search\& artist $=$ Alan+Maralung

Marett, Allan (2005), Songs, Dreamings and Ghosts: The Wangga of North Australia. Middletown: Wesleyan University Press.

Marett, Allan (2007), 'Simplifying Musical Practice in Order to Enhance Local Identity: Rhythmic Modes in the Walakandha Wangga (Wadeye, Northern Territory)'. Australian Aboriginal Studies 2007/2: 63-75.

Marett, Allan and Barwick, Linda (2007), 'Musical and Linguistic Perspectives on Aboriginal Song'. Australian Aboriginal Studies 2007/2: 1-5.

Marett, Allan, Yunupingu, Mandawuy, Langton, Marcia, Gumbula, Neparrnga, Barwick, Linda, and Corn, Aaron (2006), 'The National Recording Project for Indigenous Performance in Australia: Year One in Review', in Neryl Jeanneret and Gillian Gardiner, (eds), Backing Our Creativity. Sydney: Australia Council for the Arts, 84-90.

Martin, Nyalgodi (2003), Jadmi Junba by Nyalgodi Scotty Martin: Traditional Songman of the Dreamtime. Sydney: Rouseabout Records.

Morphy, Howard (1991), Ancestral Connections: Art and an Aboriginal System of Knowledge. Chicago: University of Chicago Press.

National Recording Project for Indigenous Performance in Australia (2011), 'National Cultural Policy Discussion Paper Submission', (Accessed 8 September 2012), (http://creativeaustralia.arts.gov.au/assets/Submission\% 20333_Redacted.pdf).

Neuenfeldt, Karl (1993), 'Yothu Yindi and Ganma: The Cultural Transposition of Aboriginal Agenda Through Metaphor and Music'. Journal of Australian Studies 17/38: 1-11.

Northern Territory Library, 'Community Stories', Northern Territory Library (Accessed 22 December 2011), (http://www.nretas.nt.gov.au/knowledge-and-history/northern-territory-library/about_us/our_story_vers ion_2_project).

O'Keeffe, Isabel (2007), 'Sung and Spoken: An Analysis of Two Different Versions of a Kun-barlang Love Song'. Australian Aboriginal Studies 2007/2: 46-62.

Papulu Apparr-kari Language and Culture Centre (2000), Yawulyu Mungamunga: Dreaming Songs of Warumungu Women, Tennant Creek, Central Australia. Sydney: Festival Records.

PARADISEC, 'Wadeye Song Database', (Accessed 22 December 2011), (http://sydney.edu.au/arts/ indigenous_song/wadeye).

Patrick, Steven, Holmes, Miles, and Box, Alan (2008), Ngurra-kurlu: A Way of Working with Warlpiri People. Alice Springs: Desert Knowledge CRC.

Perkins, Rachel and Langton, Marcia, (eds) (2008), First Australians: An Illustrated History. Melbourne: Melbourne University Publishing.

PYMedia, 'Ngaanyatjarra Media', Waru (Accessed 22 December 2011), (http://www.waru.org/organisations/ ngmedia).

Stubington, Jill and Dunbar-Hall, Peter (1994), 'Yothu Yindi's 'Treaty': Ganma in Music'. Popular Music 13/3: 243-259.

Treloyn, Sally (2007), 'Flesh with Country: Juxtaposition and Minimal Contrast in the Construction and Melodic Treatment of Jadmi Song Texts'. Australian Aboriginal Studies 2007/2 90-99.

Turpin, Myfany (2007), 'The Poetics of Central Australian Aboriginal Song'. Australian Aboriginal Studies 2007/2: 100-115.

UNESCO (2003), Convention for the Safeguarding of the Intangible Cultural Heritage. Paris: UNESCO.

Walsh, Michael (2007), 'Australian Aboriginal Song Language: So Many Questions, So Little to Work with'. Australian Aboriginal Studies 2007/2: 128-144.

Yothu Yindi Foundation (2002), Garma Statement on Indigenous Music and Performance. Darwin: Yothu Yindi Foundation.

Yunupipu, Galarrwuy (2009), 'Tradition, Truth and Tomorrow'. The Monthly 41 32-40.

Yunupinu, Mandawuy (1994), 'Yothu Yindi: Finding Balance'. Race and Class 35/4: 114-120.

Zorc, R. David (1996), Yolyu-Matha Dictionary. Batchelor: Batchelor College. 


\section{Appendix 1. Garma Statement on Indigenous Music and Performance (YYF 2002)}

Songs, dances and ceremonial performances form the core of Yolyu and other Indigenous cultures in Australia. It is through song, dance and associated ceremony that Indigenous people sustain their cultures and maintain the Law and a sense of self within the world. Performance traditions are the foundation of social and personal wellbeing, and with the ever-increasing loss of these traditions, the toll grows every year. The preservation of performance traditions is therefore one of the highest priorities for Indigenous people.

Indigenous songs should also be a deeply valued part of the Australian cultural heritage. They represent the great classical music of this land. These ancient musical traditions were once everywhere in Australia, and now survive as living traditions only in several regions. Many of these are now in danger of being lost forever. Indigenous performances are one of our most rich and beautiful forms of artistic expression, and yet they remain unheard and invisible within the national cultural heritage.

Without immediate action many Indigenous music and dance traditions are in danger of extinction with potentially destructive consequences for the fabric of Indigenous society and culture. The recording and documenting of the remaining traditions is a matter of the highest priority both for Indigenous and non-Indigenous Australians. Many of our foremost composers and singers have already passed away leaving little or no record.

At the Garma Symposium on Music and Dance held in association with the 2002 Garma Festival, the following proposals were put forward in order to address the current critical situation:

- That the establishment of local Knowledge Centres with digital storage and retrieval systems be supported as a basis for the repatriation of sound and visual records to communities. Such records play an important role in the maintenance and protection of tradition. Research should be conducted into the most culturally appropriate ways of storing and retrieving knowledge from computers. It is acknowledged that different communities may ultimately adopt different storage and delivery systems, and that there should be regular meetings to explore the success or failure of different strategies.

- That a national recording project be established to ensure that the songs of as many singers as possible are held for future generations. This project will be conducted under Indigenous control with an advisory board of senior men and women from a broad range of communities guiding its priorities and strategies.

- That the recording and repatriation of songs to local Knowledge Centres be supported by universities and other institutions to assist Indigenous communities to integrate their cultural knowledge into a broad range of community activities such as education, bilingual, and health programs; and that the maintenance of performance and ceremony be encouraged by their incorporation into community governance.

- That well documented recordings of Indigenous song be published in order to educate the broader Australian public and international audiences about Aboriginal performance traditions. The production of both the recordings and documentation should be based on broad consultation with learned senior men and women who would

10 This statement was prepared and ratified by delegates at the inaugural Symposium on Indigenous Music and Dance at Gunyanara in Arnhem Land in August 2002 during the fourth Garma Festival of Traditional Culture. 
control access to sacred knowledge in song texts. Other forms of production, including multimedia and web based forms should also be explored.

The Symposium calls on the Federal government to support and sustain Indigenous song traditions through the establishment of Knowledge Centres, and a national recording project as a National Research Priority. The Symposium resolves to pursue funding through the Australian Research Council as well as through Local, State and Territory, and Federal Government, and Industry. The participants resolved to request governments, universities, industry bodies and other institutions to acknowledge and respond to this urgent need.

This statement emanates from the Garma Symposium on Music and Dance convened by Mandawuy Yunupinu, Marcia Langton and Allan Marett at the Yirrna Music Development Centre at Gunyayara from 10 to 12 August 2002.

\section{Appendix 2. International Council for Traditional Music Statement on Indigenous Australian Music and Dance (ICTM 2011)}

The International Council for Traditional Music (ICTM), a non-governmental organization in Formal Consultative Relations with UNESCO, is a worldwide organization dedicated to the preservation of traditional music. Research conducted by members of the Australia and New Zealand branch of the ICTM reveals that Australia's traditions of Indigenous music and dance are in crisis. These traditions are among the oldest and most endangered in the world, and yet insufficient financial support is currently available to undertake the work that is required to protect and preserve them. The Australia and New Zealand Regional Committee of the ICTM, with support from the International Executive Board of the ICTM, has issued this statement to draw attention to this crisis and to call for greater support and action in this domain of endangered intangible cultural heritage.

Songs, dances and ceremonial performances lie at the centre of Indigenous Australian cultures, playing a vital role in religious beliefs and practices. They are important repositories of cultural knowledge. Through song and dance, Indigenous Australians maintain social and personal wellbeing, sustain their cultures, and maintain Law and their own identity. Performance traditions are also used to strengthen Indigenous languages and provide intergenerational links between families and communities. Indigenous songs and dances are therefore essential to Indigenous culture and society.

Once found all across Australia, these traditions now only survive in a few regions, and it is estimated that ninety-eight percent of musical traditions have already been lost. Many senior composers and performers have passed away leaving limited or no record of their knowledge. Modern lifestyles and the ongoing devastating impact of colonization are affecting the dissemination of cultural knowledge between generations. The preservation of Indigenous Australian performance traditions through recording and documenting is therefore vital for their survival.

Members of the Australia and New Zealand Regional Committee of the ICTM collaborate in projects aimed at preserving Indigenous Australian music and dance,

11 This statement was prepared by the Australia and New Zealand Regional Committee of the ICTM and endorsed unanimously by the General Assembly during the forty-first World Conference in St John's, Canada, in July 2011. 
including the establishment of Indigenous Knowledge Centres and initiatives such as the National Recording Project for Indigenous Performance in Australia. The Australia and New Zealand Regional Committee of the ICTM recognizes the benefits of these initiatives, and calls for them to be supported and expanded in any way possible. Urgent action is required to ensure the preservation of those living practices that remain, for the benefit of all Australians, and for cultural diversity worldwide.

\section{Author Biography}

Aaron Corn works with endangered intellectual traditions that remain fundamental to Indigenous cultural survival in Australia, and inform contemporary Indigenous engagements across different legal systems and cultures. He is President of Musicological Society of Australia, and a Co-Director of the National Recording Project for Indigenous Performance in Australia. He is an Associate Professor in the School of Music at the Australian National University, where he also holds an Australian Research Council Future Fellowship that seeks to apply emerging Semantic Web techniques to digital archives management for endangered cultural resources.

Email: aaron.corn@anu.edu.au 